\title{
PERANCANGAN APLIKASI KOMPARASI PERHITUNGAN HARGA POKOK PENJUALAN ANTARA METODE FIFO, LIFO DAN AVERAGE
}

\author{
Fakultas Teknologi Informasi \\ Universitas Islam Kalimantan Muhammad Arsyad Al Banjari Banjarmasin \\ Aulia Rizky Muhammad Hendrik Noor Asegaff \\ aulia.rizky.m.h.n.a@gmail.com
}

\begin{abstract}
ABSTRAK
Setiap perusahaan, apakah itu perusahaan dagang atau manufaktur dalam kegiatan operasionalnya memerlukan persediaan. Tanpa adanya persediaan para pengusaha akan dihadapkan pada resiko bahwa perusahaannya pada suatu waktu tidak dapat memenuhi keinginan para pelanggannya. Dalam perusahaan dagang memiliki satu persediaan yaitu persediaan barang dagangan sedangkan perusahaan manufaktur terdapat tiga persediaan yaitu persediaan bahan baku, persediaan barang dalam proses dan persediaan barang jadi.

Penulisan penelitian ini bertujuan untuk mengetahui barapa basarnya harga pokok penjualan dari persediaan barang jadi dengan menggunakan metode FIFO, LIFO dan Average dan untuk mengetahui dari ketiga metode tersebut mana yang lebih menguntungkan jika dilihat dari pendapatan perusahaan. Setelah melakukan komparasi perhitungan dengan menggunakan ketiga metode tersebut dapat dilihat bahwa metode Average yang mempunyai harga pokok penjualan paling kecil dan persediaan akhirnya paling besar.

Aplikasi ini dibangun dengan menggunakan Visual Basic 6.0. tampilan program yang sederhana diharapkan untuk mempermudah pemahaman dalam menjalankan proses transaksi penentuan harga pokok penjualan.
\end{abstract}

Kata Kunci : harga pokok, komparasi, FIFO, LIFO, Average 


\section{PENDAHULUAN}

Dunia usaha semakin berkembang dari hari ke hari, akibatnya setiap badan usaha dihadapkan pada situasi persaingan yang semakin ketat dalam memasarkan produknya. Bagi sebagian badan usaha, persediaan merupakan bagian yang paling aktif dalam operasi badan usaha yang secara terus menerus dibeli dan dijual. Oleh karena itu, penerapan perhitungan harga pokok pada badan usaha benar-benar diperhatikan karena perhitungan yang baik tentunya akan mempengaruhi perolehan keuntungan yang akan menjamin kelangsungan hidup badan usaha itu sendiri.

Badan usaha selalu berhubungan dengan persediaan barang sehingga harus dilaksanakan sebaik mungkin agar badan usaha tidak mengalami hambatan dan gangguan dalam beroperasi. Agar badan usaha dapat beroperasional dengan baik, pengadaan persediaan oleh badan usaha harus efektif dan efisien, sehingga tidak ada persediaan yang menumpuk akibat pembelian dalam jumlah besar. Persediaan yang menumpuk akan mengakibatkan bertambahnya biaya penyimpanan di gudang dan kualitas barang yang semakin lama akan semakin berkurang.

Di dalam penerapan persediaan yang baik, diperlukan pencatatan dan metode penilaian yang benar mengenai persediaan karena pada proses normal, persediaan akan mengalami suatu perubahan, dan untuk mengetahui perubahan tersebut, pencatatan dan penilaian yang tepat sangat penting artinya untuk menentukan metode harga pokok penjualan yang sesuai sehingga perusahaan tidak akan mengalami kerugian.
Terwujudnya perhitungan yang baik terlihat dari bagaimana suatu perhitungan dilaporkan secara benar dan akurat dalam neraca badan usaha. Agar hal tersebut dapat tercapai, dibutuhkan kembali ketelitian dan ketepatan dalam hal pencatatan, penilaian dan penetapan harga pokok.

Dari penjelasan di atas maka dapat diambil kesimpulan bahwa penerapan perhitungan harga pokok yang baik sangat penting artinya bagi suatu badan usaha dalam mengelola transaksi penjualan.

\section{RUMUSAN MASALAH}

Ditinjau dari latar belakang di atas diketahui bahwa sebuah badan usaha yang baik adalah badan usaha yang dapat mengelola harga pokok. Perumusan masalah adalah bagaimana perbandingan perhitungan harga pokok barang dengan menggunakan metode FIFO, LIFO dan Average.

\section{TUJUAN DAN TARGET LUARAN}

Tujuan yang diinginkan dari penelitian dan perancangan aplikasi ini adalah mempermudah perusahaan dalam menetapkan harga pokok penjualan barang dengan komparasi metode FIFO, LIFO dan Average. Aplikasi ini meliputi pencataan laporan pembelian dan penjualan, data supplier, laporan komparasi perhitungan harga pokok serta laporan stok barang.

Target luaran dalam pembuatan laporan penelitian ini adalah agar bisa dimanfaatkan bagi perusahaan sebagai aplikasi untuk menetapkan harga pokok penjualan barang.

\section{MANFAAT PENELITIAN}


Dalam pembuatan penelitian tentu saja harus ada manfaat yang harus didapat. Berikut manfaat penelitian :

1. Menambah pengetahuan tentang pengelolaan barang, terutama mengenai penentuan harga pokok penjualan.

2. Mempermudah menentukan harga pokok penjualan dengan metode FIFO, LIFO dan Average.

3. Menjadi referensi bagi penelitipeneliti berikutnya untuk membuat sesuatu yang lebih relevan.

\section{METODE PENELITIAN}

\section{Metode Pengumpulan Data}

Metode pengumpulan data yang digunakan pada system informasi ini adalah :

a. Metode Observasi, yaitu mengamati langsung serta terlibat langsung dalam kegiatan.

b. Metode wawancara, yaitu pengumpulan data yang dilakukan dengan wawancara berupa tanya jawab meupun penjelasan-penjelasan yang bersifat umum.

c. Metode kepustakaan, yaitu pengambilan data berdasarkan referensi atau buku-buku karya ilmiah yang dapat memberikan inforamasi.

\section{Tahapan Penelitian}

Tahapan-tahapan dalam penelitian antara lain :

a. Menentukan objek, yaitu masalah yang berkaitan dengan perhitungan harga pokok penjualan barang.

b. Identifikasi masalah, yaitu mencari penyebab masalah yang terjadi sehingga sasaran dapat tercapai.

c. Menganalisa masalah, yaitu mencari apa yang tepat dalam menentukan metode perhitungan harga pokok penjualan barang.

d. Membuat desain system dan program aplikasinya.

e. Mengimplementasikan program.

\section{Diagram Konteks}

Diagram Konteks, merupakan diagram yang menggambarkan hubungan sistem dengan yang diluar sistem. Berikut ini adalah gambar Diagram Konteks Sistem Informasi Penjualan :

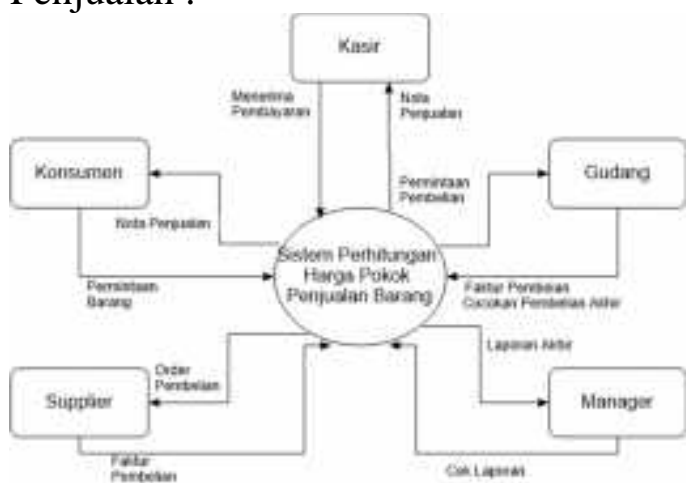

Gambar 1. Diagram Konteks

\section{DFD (Data Flow Diagram)}

Data Flow Diagram adalah refresentasi grafik dari sebuah sistem. DFD menggambarkan sebuah sistem yang telah ada atau baru yang akan dikembangkan secara logika tanpa mempertimbangkan lingkungan fisik dimana data tersebut akan disimpan.

Dibawah ini adalah DFD Level 0 dari sistem : 


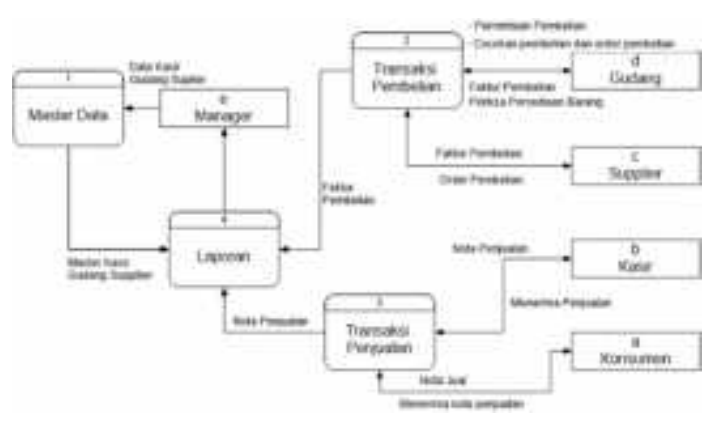

Gambar 2. DFD Level 0

\section{Desain Data Base}

Langkah pertama yang dilakukan dalam perancangan program adalah merancang tabel atau database yang akan dibuat agar mempermudah dalam menampung data yang akan dibuat.

\section{a. Kamus Data}

Kamus data (KD) atau juga disebut dengan istilah data dictionary adalah katalog fakta tentang data dan kebutuhan menggunakan Kamus Data (KD), analisa sistem dapat mendefinisikan data yang mengalir di sistem dengan lengkap.

Kamus data (KD) dibuat pada tahap analisa sistem dan digunakan baik pada tahap analsis maupun pada tahap perencanaan sistem. Pada tahap analisis, kamus data dapat digunakan sebagai alat komunikasi antara analisis sistem dengan pemakain sistem tentang data yang menglair di sistem, yaitu tentang data yang masuk ke sistem dan tentang informasi yang dibutuhkan oleh pemakai sistem, pada tahap perencanaan sistem, kamus data untuk merancang input ( masukan ), merancang laporan-laporan dan database.

\section{b. Struktur Tabel dalam Database}

File merupakan kumpulan dari item data yang di atur di dalam suatu record, dimana item-item data tersebut dimanipulasi untuk proses tertentu. Struktur file dibuat sebagai pendukung agar pemakai (user) mengetahui segala yang berhubungan dengan pengolahan database.

\section{Relasi Antar Tabel}

Setelah tabel dibuat maka diperlukan relasi diantara tabel. Dimana relasi tersebut berfungsi untuk mengtahui data mana saja yang akan berhubungan untuk menunjang data pada setiap tabel untuk tabel yang lain. Berikut gambar relasi tabel yang dibentuk.

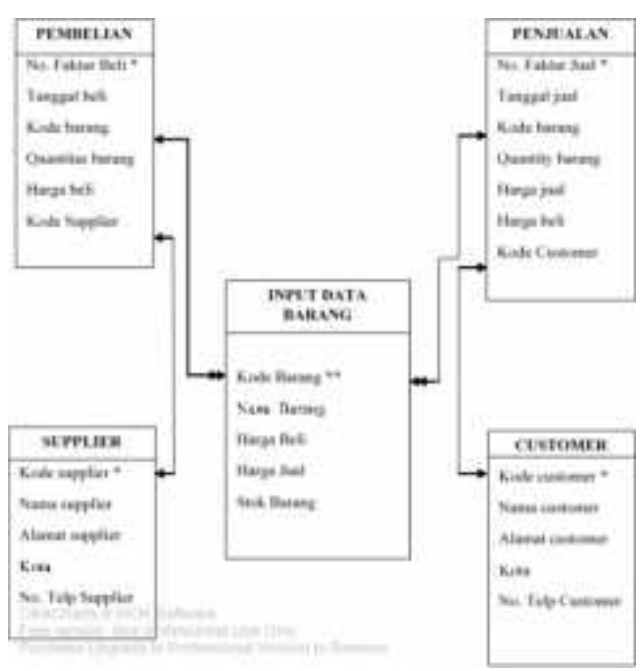

Gambar 3. ER Diagram Penjualan

\section{Perancangan Antar Muka}

Perancangan antar muka dirancang untuk memudahkan user dalam mengakses Sistem Informasi yang dibutuhkan. Rancangan struktur menu dibuat untuk memudahkan user dalam melakukan penggunaan fungsi-fungsi program yang ada pada sistem ini. 


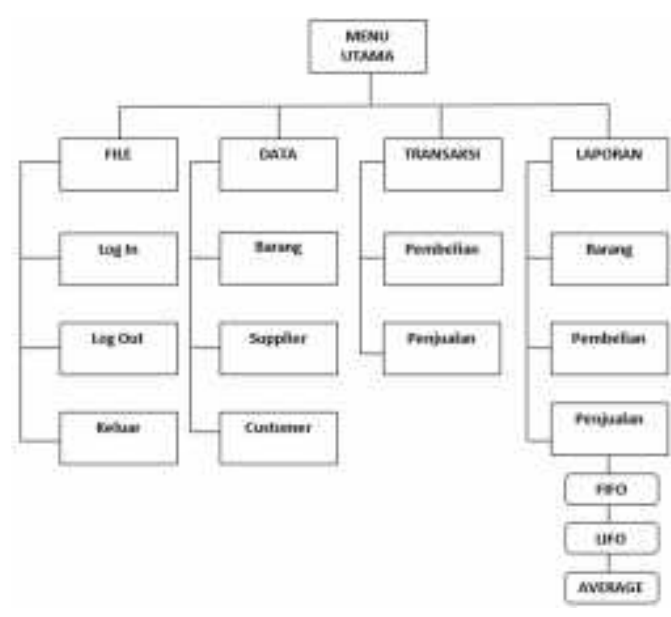

Gambar 4. Stuktur Menu Penjualan Barang

\section{ANALISA HASIL DAN PEMBAHASAN}

\section{Perancangan Desain Program}

\section{a. Form Login}

Form login merupakan form yang digunakan untuk membuat form menu utama. Jika seorang user tidak memiliki user name atau password maka hak akses untuk membuka form tersebut ditolak. Untuk itu, pihak user yang belum mempunyai password maupun user name harus segera menghubungi pihak admin yang bersangkutan. Pihak admin di sini memiliki hak akses khusus untuk memberikan user name. Adapun form login tersebut dapat dilihat pada gambar di bawah ini :

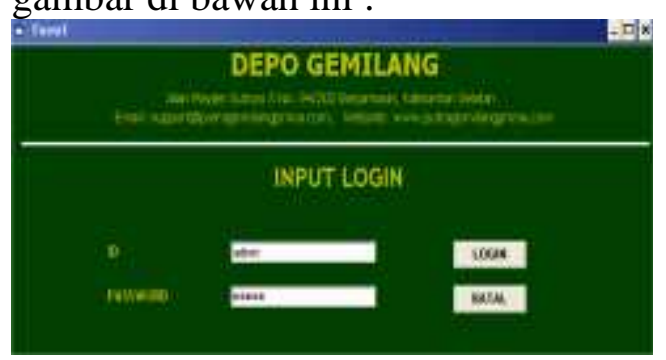

Gambar 5 Desain Login

Apabila password yang dimasukan salah maka muncul message box seperti gambar di bawah ini :

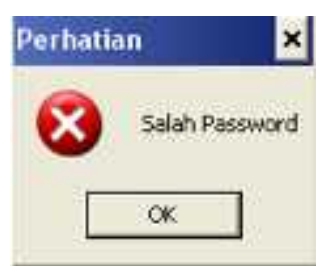

Gambar 6. Menu Pengisian Password Salah

\section{b. Form Menu Utama}

Dibawah ini adalah desain menu utama, pada desain menu utama ini terdapat toolbar yang memungkinkan user memilih menu yang diinginkan. Toolbar pada desain menu utama ini terdiri dari input data user, input data supplier, input data barang, input data pembelian, dan input data penjualan yang digunakan untuk memasukkan data-data yang sesuai. Stok barang untuk mengetahui jumlah barang yang tersedia. Ditambahkan pula cetak data supplier, cetak laporan pembelian dan cetak laporan penjualan yang digunakan untuk mencetak laporan transaksi.

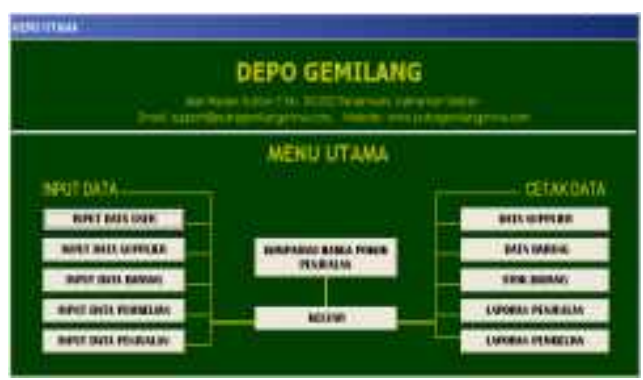

Gambar 7. Desain Menu Utama

\section{c. Form Input Data User}

Gambar di bawah ini adalah desain menu input data user. Fungsi dari desain input data user untuk memasukkan data-data user / pengguna yang terdiri dari ID pengguna, password dan nama lengkap. Disediakan pula tombol untuk menyimpan data-data pengguna. Apabila kode yang dimasukkan telah ada pada daftar 
maka data yang sama tidak dapat disimpan. Tombol simpan untuk menyimpan data, hapus untuk menghapus, edit untuk mengedit data dan tombol keluar untuk kembali ke menu utama.

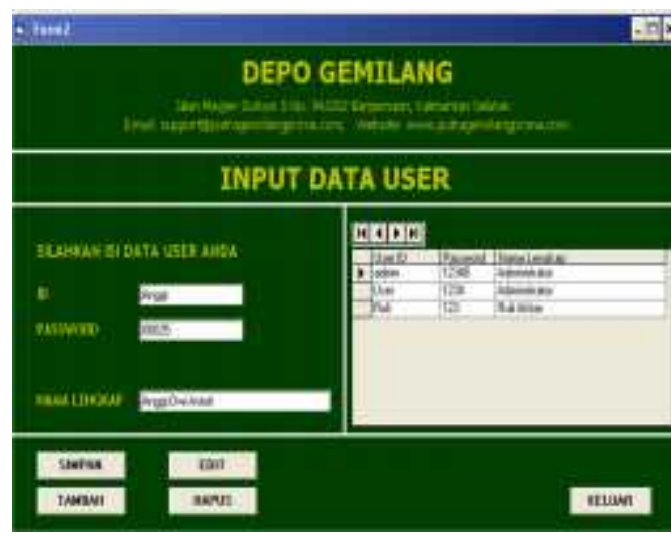

Gambar 8. Form Input Data User

\section{d. Form Input Data Supplier}

Gambar di bawah ini adalah desain menu input data supplier. Fungsi dari desain input data supplier ini untuk memasukkan data-data supplier seperti kode supplier, nama supplier, alamat supplier dan kota supplier. Ditambahkan pula tombol untuk menyimpan data supplier, apabila kode yang dimasukkan telah ada maka data yang sama tidak dapat disimpan. Tombol simpan untuk menyimpan data, hapus untuk menghapus data, edit untuk mengedit data, cari untuk mencari data supplier dan tombol keluar untuk kembali ke menu utama.

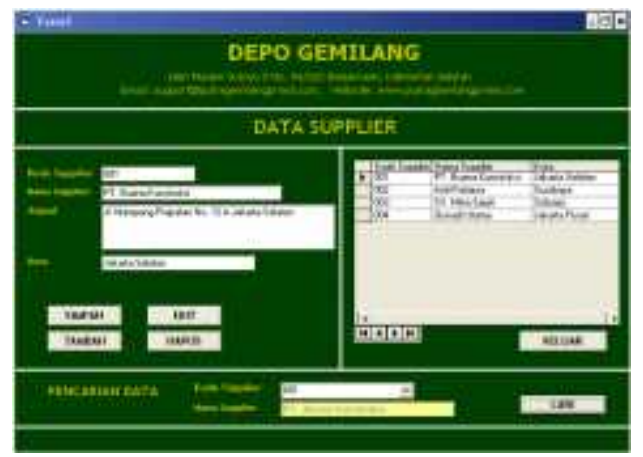

Gambar 9. Input Data Supplier

\section{e. Form Input Data Barang}

Gambar di bawah ini adalah desain menu input data barang. Fungsi dari desain input data barang ini untuk memasukkan data-data barang sebagai persediaan. Desain input data barang ini terdiri dari kode barang dan nama barang. Ditambahkan pula tombol untuk menyimpan data barang, apabila kode yang dimasukkan telah ada pada daftar maka data yang sama tidak dapat disimpan. Tombol simpan untuk menyimpan data, edit untuk mengedit data, tambah untuk menambahkan data, hapus untuk menghapus data, dan keluar untuk kembali ke menu utama.

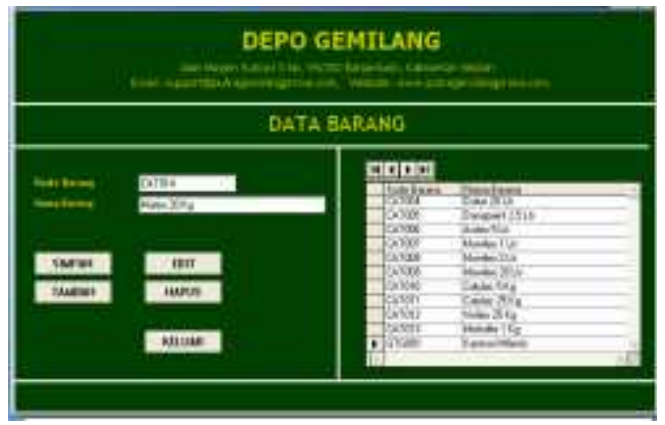

Gambar 10. Form Input Data Barang

\section{f. Form Input Data Pembelian}

Gambar di bawah ini adalah desain input data pembelian. Fungsi dari desain input data pembelian ini untuk memasukkan data-data pembelian barang. Desain input pembelian barang trdiri dari nama barang, nama supplier, jumlah pembelian dan harga penjualan. Disediakan pula tombol simpan untuk menyimpan data, tambah untuk menambah, hapus untuk menghapus, dan tombol keluar untuk kembali ke menu utama. 


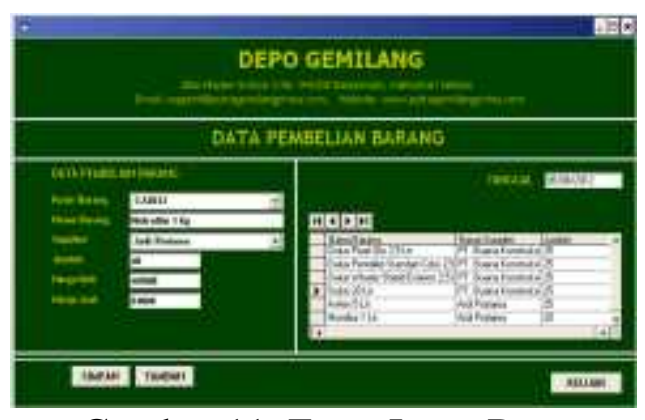

Gambar 11. Form Input Data Pembelian

\section{g. Form Komparasi Harga Pokok Penjualan}

Gambar di bawah ini adalah desain input data untuk komparasi harga pokok penjualan serta menentukan harga jual untuk barang tertentu. Dalam form ini merupakan proses penentuan harga dengan metodeLIFO, FIFO dan Average. Desain input data komparasi harga pokok penjualan ini terdiri dari kode barang, nama barang, kolom harga untuk LIFO, FIFO dan Average. Disediakan pula tombol tambah untuk menambah data barang, hapus untuk menghapus, cetak untuk mencetak faktur dan tombol keluar untuk kembali ke menu utama.

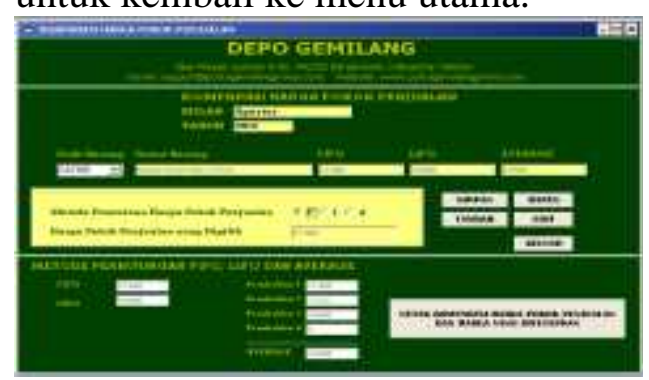

Gambar 12. Form Komparasi Harga Pokok Penjualan

\section{h. Form Input Data Penjualan}

Gambar di bawah ini adalah desain input data penjualan. Fungsi dari desain input ini untuk memasukkan data-data barang yang dijual. Desain input data penjualan ini terdiri dari nomor faktur penjualan, tanggal dan nama customer. Disediakan pula tombc ${ }^{1}$ tambah untuk menambah data barang, hapus untuk menghapus, cetak untuk mencetak faktur dan tombol keluar untuk kembali ke menu utama.

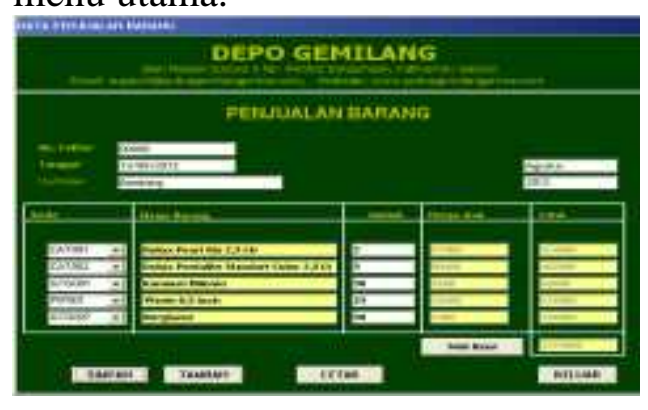

Gambar 13. Form Input Data Penjualan

\section{Output Data}

a. Output Data Barang

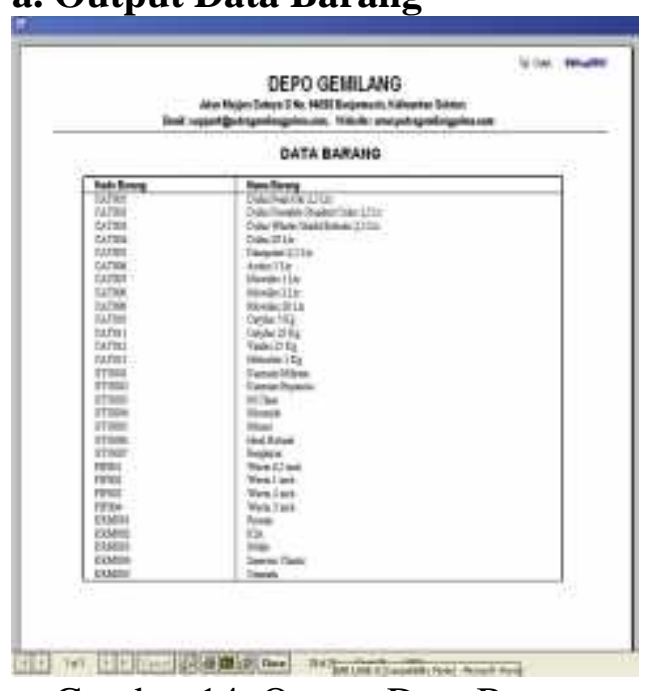

Gambar 14. Output Data Barang

\section{b. Output Data Supplier}




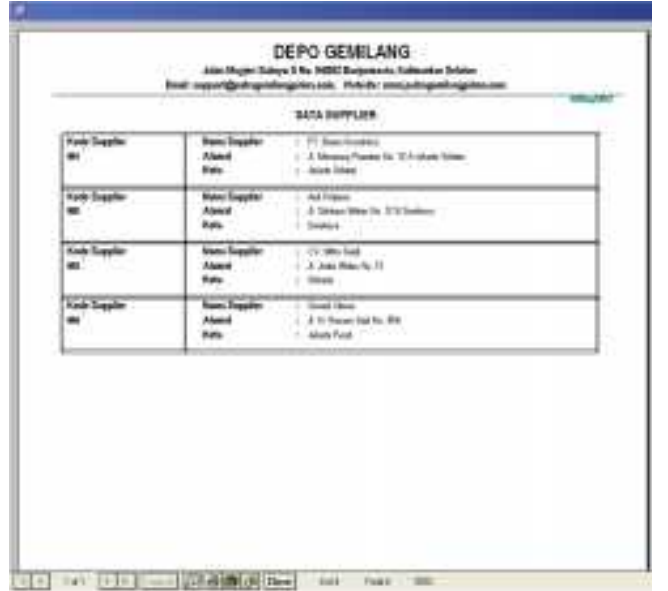

Gambar 15. Output Data Supplier

\section{c. Output Laporan Pembelian}

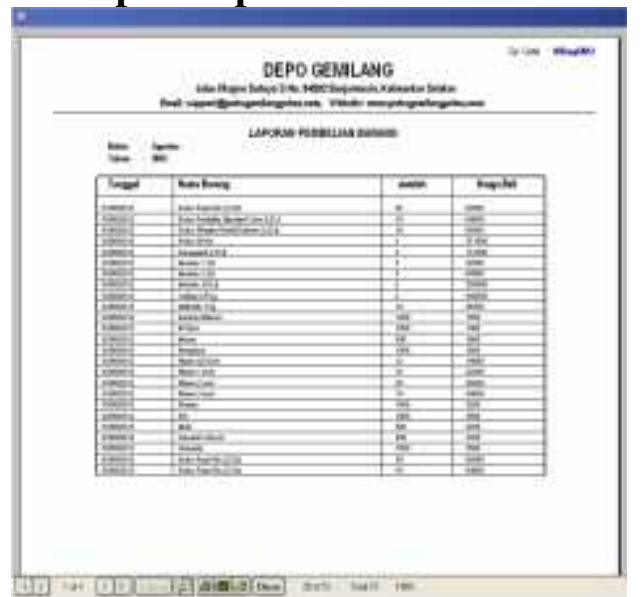

Gambar 16. Output Laporan Pembelian

\section{d. Output Laporan Komparasi} Harga Pokok Penjualan

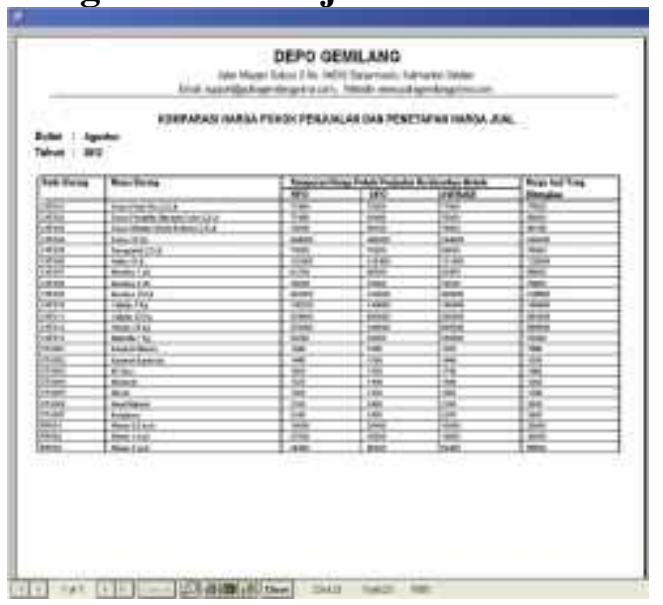

Gambar 17. Output Laporan Komparasi Harga Pokok Penjualan

\section{e. Output Laporan Penjualan}

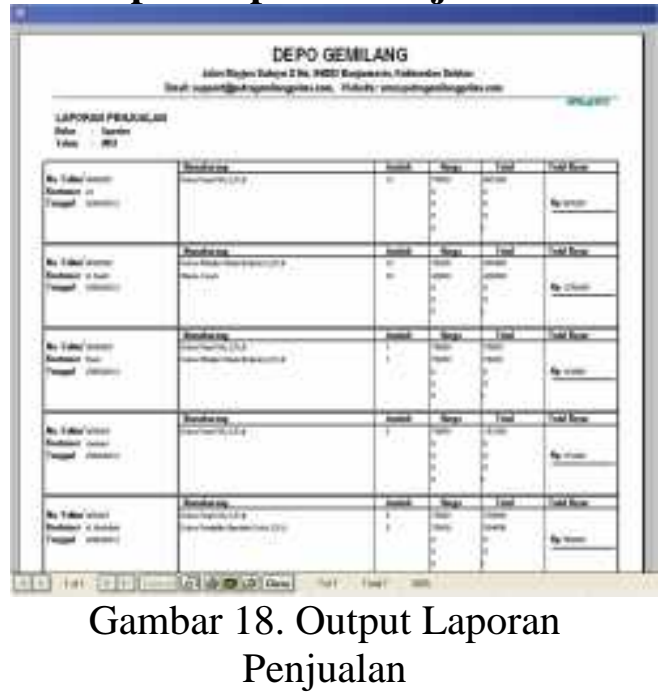

\section{f. Output Faktur Penjualan}

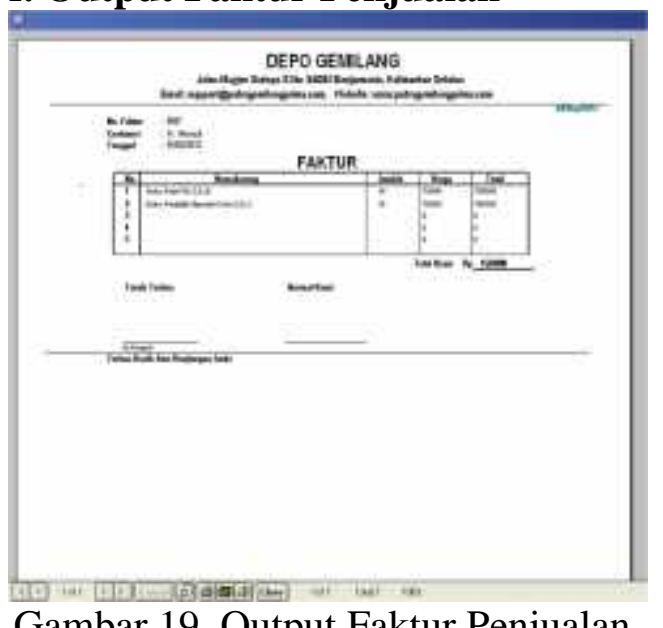

Gambar 19. Output Faktur Penjualan

\section{g. Output Stok Barang}

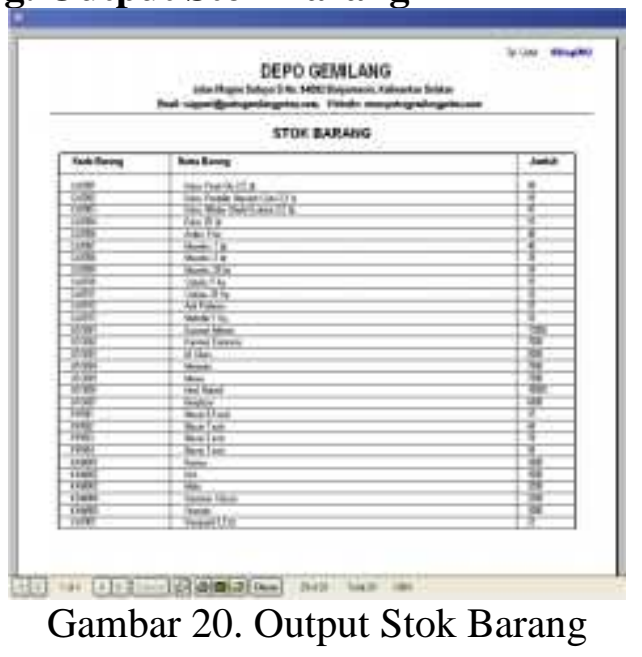

Jurnal Ilmiah “Technologia" 


\section{KESIMPULAN}

Dari hasil observasi dan dilakukan pengujian maka dapat ditarik kesimpulan yaitu Sistem Perhitungan Harga Pokok penjualan Barang ini dirancang untuk membantu perusahaan dalam proses penglohan data dan transaksi. Aplikasi ini dirancang untuk menentukan harga pokok penjualan yang mana bisa lebih menguntungkan untuk perusahaan.

Dengan menggunakan komputerisasi dan metode FIFO, LIFO dan Average dalam menentukan harga pokok penjualan maka perusahaan akan lebih cepat menuntukan harga pokok penjualan. Diharapkan aplikasi ini nantinya dapat dikembangkan dan disempurnakan seiring berkembangnya spesifikasi kebutuhan yang harus dipenuhi dalam mencapai hasil yang lebih baik. Dalam menggunakan aplikasi ini, perusahaan masih harus memelih metode mana yang terbaik dalam menentukan harga pokok penjualan yang mana dapat meningkatkan keuntungan pagi perusahaan. Pada aplikasi ini perlu diperbaiki pada informasi harga penjualan barang, serta perlu ditambahkan fungsi untuk mengetahui stok minimum agar perusahaan dapat mengantipasi kekurangan stok barang.

Perusahaan juga dapat terbantu untuk melakukan pengontrolan persediaan barang sehingga dapat mengatisipasi kekosongan stok.

\section{DAFTAR PUSTAKA}

Daryanto, Drs., Belajar Komputer Visual Basic, CV. Yrama Widya, Bandung, 2003.

\footnotetext{
Djoko, Pramono, Mudah Menguasai Visual Basic 6, PT. Elex Media Komputindo, Jakarta, 1999.
}

Jusup, Al. Haryono, 2005, Dasardasar Akuntansi, Jilid Dua, Edisi Enam, Bagian Penerbitan Sekolah Tinggi Ilmu Ekonomi YKPN, Yogyakarta.

\section{Reeve, James. M, dkk, 2009,Pengantar Akuntansi Adaptasi Indonesia, Buku Satu, Penerbit Salemba Empat, Jakarta.}

Soemarso S.R, 2002, Akuntansi Suatu Pengantar, Buku Satu, Edisi Kelima, Penerbit Salemba Empat, Jakarta.

STMIK Indonesia. 2011, Buku Panduan Penulisan Karya Ilmiah STMIK Indonesia Banjarmasin, Banjarmasin.

http://repository.usu.ac.id/bitstream/1 23456789/20970/4/Chapter\%2 0II.pdf (diakses tanggal 2

Desember 2011) 